\title{
Inflammatory and Immune Disorders Associated with Myelodysplastic Syndromes
}

\author{
Vincent Jachiet ${ }^{1,2}$, Pierre Fenaux ${ }^{3}$, Anna Sevoyan ${ }^{4}$, Yervand Hakobyan ${ }^{4}$, Lionel Ades ${ }^{3}{ }^{-}$, Olivier Fain ${ }^{1,2}$, \\ Arsène Mekinian ${ }^{1,2, *}$ and on behalf of the MINHEMON and GFM ${ }^{+}$
}

1 Department of Internal Medicine, Inflammation-Immunopathology-Biotherapy Department (DHU i2B), Assistance Publique-Hôpitaux de Paris, Hôpital Saint-Antoine, Sorbonne Université, 75012 Paris, France; vincent.jachiet@aphp.fr (V.J.); olivier.fain@aphp.fr (O.F.)

2 Centre de Recherche Saint-Antoine (CRSA), INSERM U938, Sorbonne Universités, 75012 Paris, France

3 Department of Hematology, Assistance Publique-Hôpitaux de Paris, Hôpital Saint Louis, 75010 Paris, France; pierre.fenaux@aphp.fr (P.F.); lionel.ades@aphp.fr (L.A.)

4 Department of Hematology and Transfusion Medicine, National Institute of Health, Yerevan 0051, Armenia; sevoyananna6@gmail.com (A.S.); yero75@yahoo.com (Y.H.)

* Correspondence: arsene.mekinian@aphp.fr

+ MINHEMON: French Network of dysimmune disorders associated with hemopathies, GFM: Groupe Francophone des Myélodysplasies.

Citation: Jachiet, V.; Fenaux, P.; Sevoyan, A.; Hakobyan, Y.; Ades, L.; Fain, O.; Mekinian, A.; on behalf of the MINHEMON and GFM. Inflammatory and Immune Disorders Associated with Myelodysplastic Syndromes. Hemato 2021, 2, 329-346. https://doi.org/10.3390/hemato2020019

Academic Editor: Claire Harrison

Received: 6 April 2021

Accepted: 18 May 2021

Published: 24 May 2021

Publisher's Note: MDPI stays neutral with regard to jurisdictional claims in published maps and institutional affiliations.

Copyright: (c) 2021 by the authors. Licensee MDPI, Basel, Switzerland. This article is an open access article distributed under the terms and conditions of the Creative Commons Attribution (CC BY) license (https:/ / creativecommons.org/licenses/by/ $4.0 /)$.

\begin{abstract}
Systemic auto-inflammatory or autoimmune diseases (SIADs) develop in up to a quarter of patients with myelodysplastic syndromes (MDS) or chronic myelomonocytic leukemia (CMML). With or without the occurrence of SIADs, the distribution of MDS subtypes and the international or CMML-specific prognostic scoring systems have been similar between MDS/CMML patients. Moreover, various SIADs have been described in association with MDS, ranging from limited clinical manifestations to systemic diseases affecting multiple organs. Defined clinical entities including systemic vasculitis, connective tissue diseases, inflammatory arthritis and neutrophilic diseases are frequently reported; however, unclassified or isolated organ impairment can also be seen. Although the presence of SIADs does not impact the overall survival nor disease progression to acute myeloid leukemia, they can help with avoiding steroid dependence and make associated adverse events of immunosuppressive drugs challenging. While therapies using steroids and immunosuppressive treatment remain the backbone of first-line treatment, increasing evidence suggests that MDS specific therapy (hypomethylating agents) and sparing steroids may be effective in treating such complications based on their immunomodulatory effect. The aim of this review was to analyze the epidemiological, pathophysiological, clinical and therapeutic factors of systemic inflammatory and immune disorders associated with MDS.
\end{abstract}

Keywords: myelodysplastic syndrome; chronic myelomonocytic leukemia; autoimmune disease; inflammatory diseases; hypomethylating agents

\section{Introduction}

Myelodysplastic syndromes (MDS) are clonal hematopoietic stem cell disorders predominant in the elderly population, characterized by ineffective and dysplastic hematopoiesis, leading to one or more cytopenias. Chronic myelomonocytic leukemia (CMML) is characterized by persistent monocytosis with medullar dysplastic features. Patients with MDS/CMML are at risk of symptomatic anemia, infection and bleeding and with risk of transformation to acute myeloid leukemia (AML) [1]. The pathophysiology of MDS/CMML is complex and not fully understood and is characterized by a multi-step process involving cytogenetic changes and/or gene mutations in a hematopoietic stem cell [2] where alterations in the function of the bone marrow microenvironment-or niche-[3] and widespread gene hypermethylation at advanced stages [4,5] result in an accumulation of abnormal, 
immature myeloid cells in the bone marrow and the impairment of normal hematopoiesis. In the last few years, diagnosis, prognostic staging and management of MDS/CMML has changed with the emergence of blood and/or bone marrow next-generation sequencing (NGS), which has allowed doctors to identify somatic mutations in more than $90 \%$ patients suffering from MDS/CMML [6].

In the 1980s, Mufti et al. reported the existence of immunological abnormalities in 104 patients with MDS including polyclonal hypergammaglobulinemia, hypogammaglobulinemia, positive direct antiglobulin test, organ and non-organ specific autoantibodies and clinical diseases such as pernicious anemia, hypothyroidism or seronegative rheumatoid arthritis [7]. Since then, various systemic inflammatory or autoimmune diseases (SIADs) have been reported (Figure 1). In 2002, SIADs were categorized into five groups: systemic vasculitis, connective tissue disorders (such as systemic lupus erythematosus and Sjogren's syndrome), isolated autoimmune manifestations (such as skin vasculitis, polyneuropathy, glomerulonephritis and vitiligo), immunological-mediated hematological abnormalities (including immune thrombocytopenia and autoimmune hemolytic anemia) and asymptomatic serological immunologic abnormalities (such as cryoglobulinemia, antinuclear antibodies, polyclonal hypergammaglobulinemia and positive direct antiglobulin test) [8].

The features of these MDS-related disorders differ from idiopathic autoimmune or inflammatory diseases, with more frequent unclassified and incomplete forms $[9,10]$. In the presence of features consistent with autoimmune or inflammatory disorders, the pathophysiological link between both disorders should be determined since fortuitous association could be raised. The aim of this review was to analyze the epidemiological, pathophysiological, clinical and therapeutic factors of systemic inflammatory and immune disorders associated with MDS.

Systemic vasculitis

Giant cell arteritis

Behçet's-like syndrome

Polyarteritis nodosa

ANCA-positive vasculitis

Cryoglobulinemia vasculitis

IgA vasculitis

Connective tissue diseases

Relapsing polychondritis

Systemic lupus erythematosus

Primary antiphospholipid syndrome

Myositis

Sjogren's syndrome

\section{Inflammatory arthritis}

Polymyalgia rheumatica

Rheumatoid arthritis

RS3PE syndrome

Undifferentiated arthritis

Chronic CPP crystal inflammatory arthritis

\section{Skin manifestations}

Neutrophilic dermatosis:

- Sweet syndrome

- Pyoderma gangrenosum

Leucocytoclastic vasculitis

Cutaneous granulomatosis

\author{
Autoimmune cytopenias \\ Autoimmune hemolytic anemia \\ Immune thrombocytopenia \\ Evans syndrome \\ Chronic idiopathic neutropenia
}

\section{VEXAS syndrome}

Unclassified or limited clinical manifestations
Unexplained recurrent fever
Pleurisy
Peritonitis
Thrombosis : venous thromboembolism
Pulmonary alveolar proteinosis
Inflammatory bowel disease

Laboratory immune abnormalities

Persistently elevated CRP

Cryoglobulinemia

Antinuclear antibodies

Antiphospholipid antibodies

Anti-neutrophil cytoplasmic antibody

Rheumatoid factor

Anti-citrullinated peptide antibodies

Anti-tissue antibodies

Polyclonal hypergammaglobulinemia

Positive Coombs test

Figure 1. The spectrum of inflammatory and immune disorders associated with myelodysplastic syndromes. RS3PE: Remitting seronegative symmetrical synovitis with pitting edema; CPP: calcium pyrophosphate; CRP: C-reactive protein. 


\section{Epidemiology}

According to the largest retrospective series, various SIADs can be associated with MDS or CMML [10-15]. The prevalence and incidence may vary because of differing definitions of SIADs among physicians, disparities in patient's selection and the small number of included patients. Autoimmune diseases are more frequent in patients with MDS than without MDS ( $32 \%$ vs. $4 \%, p<0.001)$ [16] or those with lymphoid malignancies (5-7\%) [17]. Conversely, patients with a prior autoimmune disease have an increased risk for developing MDS [18-20] with an odds ratio varying between 1.5 and 3.5, although the contribution of immunosuppressive/cytotoxic drugs cannot be excluded.

Patients with MDS-associated SIADs appear to be younger in age with a median age of 67-70 years $[10,15]$ versus the age range of $71-73$ years having an absence of SIADs. Regarding sex [1], MDS-associated SIADs disappear considerably in male patients with MDS [11,15].

Autoimmune disorders precede the diagnosis of MDS or occur concomitantly with MDS in 30\% of cases. In the remaining cases, SIADs develop during the course of MDS with a median time of eight months [10]; however, they have been shown to sometimes emerge several years after MDS onset [16].

\section{Pathophysiology of MDS-Related Immune Dysregulation Disorders}

Various immune disorders have been described in MDS patients. An aberrant response of both innate and adaptive immune system is reported during MDS depending on the stage of MDS:

- Low-risk MDS is characterized by increased apoptosis of hematopoietic progenitors [21,22] secondary to: (i) the production of pro-inflammatory cytokines such as interleukin 6 (IL-6) or tumor necrosis factor alpha (TNF- $\alpha$ ) [21,23-27], (ii) the expansion of oligoclonal CD8 T lymphocytes directed against Wilms' tumor 1 (WT1) antigen or other epitopes overexpressed by the myelodysplastic clone [28-30] and (iii) a Th17/Treg imbalance characterized by a quantitative and functional defect of $\mathrm{T}$ regulatory lymphocytes (Treg) associated with an excessive Th17 response [31-33].

- $\quad$ High-risk MDS is characterized by excess proliferation secondary to: (i) acquisition of resistance to apoptosis by overexpression of the anti-apoptotic TNFR2 receptors of TNF- $\alpha[34,35])$, (ii) an escapement of the anti-tumor response to the malignant clonal cells [36] by an increase of functional T regulatory lymphocytes $[37,38]$ and (iii) a lack of cytotoxicity of NK cells [34,39] and expansion of myeloid-derived suppressor cells (MDSC) $[40,41]$.

Studies analyzing the pathophysiological mechanisms and factors in patients with MDS-related SIADs is limited. However, different hypotheses have been raised including:

- Th17/Treg imbalance reported during low risk MDS could promote the emergence of dysimmune manifestations through an excess of pro-inflammatory Th17 lymphocytes and a defect of regulatory $\mathrm{T}$ lymphocytes at the origin of an immune tolerance breakdown.

- $\quad$ A higher level of interferon regulatory factor 1 (IRF-1), a mediator of type 1 interferonsignaling pathway demonstrated in MDS patients with SIADs compared to MDS patients without SIADs [42].

- $\quad$ During CMML, increased secretion of cytokines such as TNF- $\alpha$ and IL- 6 caused by the proliferation of monocytes could promote polyclonal proliferation of B lymphocytes and the production of auto-antibodies. Additionally, a defect in antigen presentation by macrophages could lead to the persistence of deleterious chronic immune activation.

- $\quad$ The quantitative and functional decrease in T- $\gamma \delta$ lymphocytes in patients with MDS associated with SIADs could be comparable to that observed in patients with isolated autoimmune diseases [43]. 
- $\quad$ The inactivating mutations of TET2 and DNMT3A could favor a pro-inflammatory state of monocytic and macrophagic cells $[44,45]$ and/or modify the activity of CD8 T lymphocytes and the polarization of the CD4 T lymphocytes, since TET2 regulates the methylation of the promoter regions of FOXP3 gene [46] and genes of transcription factors TBET, GATA3 and RORgT [47].

- Activation of autoinflammatory pathways (NOD-like receptor family pyrin domain containing 3, or Familial Mediterranean Fever Gene) in the clonal cells of myeloid disorders may be involved in the pathophysiology of myeloid malignancy-associated neutrophilic dermatoses [48-50].

To date, most studies have not made a clear distinction between primarily autoimmune conditions (involving adaptive immunity such as rheumatoid arthritis and Sjögren's syndrome) and autoinflammatory conditions involving innate immunity, such as Crohn disease $[21,51]$. Watad and Kacar recently postulated that autoinflammatory disorders could be more common in MDS than autoimmune diseases given the links between autoinflammation and MDS within myeloid lineage cells [52].

\section{Characteristics of the Underlying MDS}

Among the different series reported in the literature, there is variability in the distribution of MDS subtypes that may reflect different periods and changes of World Health Organization (WHO) classifications. In a recent cohort of 89 patients and extensive literature review [14], the distribution of MDS subtypes, the international prognostic scoring system (IPSS) and CMML-specific prognostic scores (CPSS) were similar between MDS/CMML patients with or without SIADs. Most studies failed to identify a correlation between the types of MDS and SIADs. Nevertheless, several authors emphasized the link between CMML and vasculitis $[53,54]$. Concerning MDS cytogenetic features, the karyotype distribution did not appear to be influenced by the presence of SIADs. Moreover, the rates of favorable cytogenetic findings (normal karyotype, $\operatorname{del}(5 q)$, del(20q) or $-Y$ ) did not differ between MDS patients with or without SIADs [10,11,42].

Associations between phenotype and genotype have been recently identified within SIADs that are associated with MDS. Wesner et al. reported a French retrospective caseseries with a literature review of 39 patients with Behçet's-like syndrome associated with trisomy- 8 positive MDS, characterized by orogenital aphtosis, skin features and severe ulcerative digestive disease of ileocecal distribution [55]. Other clinical manifestations of Behçet's disease, such as arthritis or neutrophilic dermatosis, have also been described in MDS patients with trisomy 8, with the exception of ocular and neurologic manifestations that are usually absent. Other inflammatory manifestations associated with MDS with trisomy 8 have been reported less frequently: pyoderma gangrenosum (PG) [56], sweet syndrome (SS) [57], pulmonary alveolar proteinosis [58] and inflammatory arthritis [59]. Moreover, Zhao et al. reported a higher incidence of TET2/IDH and SRSF2 mutations in a cohort of MDS/CMML patients with SIADs compared to MDS/CMML patients without, and identified that TET2/IDH and not SRSF2 mutations deeply modified the Treg and CD8+ T-cell subsets distribution [60]. Similarly, Oh et al. found a higher incidence of TET2 mutations in a cohort of MDS/CMML patients with SIADs [61].

\section{Autoimmune Disorder Characteristics}

Various autoimmune and inflammatory diseases have been described in MDS patients. In a French cohort of 123 patients with MDS/CMML, systemic diseases were classified as vasculitis $(32 \%)$, connective tissue diseases $(25 \%)$, inflammatory arthritis $(23 \%)$, neutrophilic diseases $(10 \%)$ or unclassified disorders (11\%) [10].

\subsection{Systemic Vasculitis}

MDS/CMML-associated vasculitis displayed a highly wide clinical spectrum without any correlation to the hematological disease status. In a French retrospective cohort of 70 patients with MDS/CMML-associated vasculitis, the main subtypes included giant cell 
arteritis (GCA) in 24 patients (34\%), Behçet's-like syndrome in 11 patients $(20 \%)$, polyarteritis nodosa in six patients (9\%), ANCA-positive vasculitis in seven patients $(10 \%)$ among which five had microscopic polyangiitis and two with granulomatosis with polyangiitis, cryoglobulinemia vasculitis in three patients (4\%), IgA vasculitis in two patients (3\%) [62]. Unclassified vasculitis was observed in 17 patients $(24 \%)$ characterized with symptoms suggestive of vasculitis (unexplained fever, weight loss, arthritis, purpura, deep vein thrombosis and/or eye involvement with histological evidence of leukocytoclastic vasculitis). This study showed no correlation of vasculitis diagnoses with subtypes and severity of MDS/CMML, and there was no impact of vasculitis on overall survival in comparison to MDS/CMML without vasculitis.

As idiopathic GCA is the most frequent vasculitis in older persons, it remains difficult to distinguish fortuitous co-occurrence of the two distinct diseases from a paraneoplastic inflammatory disease. A French retrospective cohort and literature review of 41 patients with MDS-associated GCA identified that: (i) a clinical phenotype with a lower incidence of cephalic symptoms, due to the prevalence of headaches, jaw claudication and anterior ischemic optic neuropathy, was significantly lower in patients with MDS/CMML-associated GCA compared to MDS/CMML-free "idiopathic" GCA; and (ii) a decreased hemoglobin levels, platelet and neutrophil counts occurred [63]. Conversely, other clinical (frequencies of polymyalgia rheumatica and aortitis), laboratory (C-reactive protein (CRP) levels) and histopathological (positive temporal arteries biopsies) GCA features did not differ in idiopathic and MDS-associated GCA. MDS/CMML-associated GCA were characterized by a higher risk of relapse and steroid dependence compared to idiopathic GCA.

\subsection{Connective Tissue Diseases}

Connective tissue diseases (CTDs) account for a quarter of MDS-related SIADs in a French cohort [10], mostly of relapsing polychondritis (RP) (45\%) and systemic lupus erythematosus (SLE) $(26 \%)$.

In Dion et al., a French monocentric cluster analysis of 142 patients with relapsing polychondritis identified three distinct phenotypes including a "hematologic" phenotype in 12 patients ( $9 \%$ ) characterized by a concomitant hematologic malignancy mainly MDS (83\% of cases) [64]. The most severe phenotype occurred frequently in older men and was strongly associated with skin and cardiac involvements, general symptoms and refractory disease. Although usual manifestations (chondritis and arthritis) are common in the MDSassociated RP, only one patient showed mild tracheobronchial involvement. Neutrophilic dermatoses, especially SS were frequently associated to RP in patients with MDS [65-67].

Besides peripheral cytopenias, bone marrow (BM) abnormalities were reported in patients with SLE, including myelofibrosis, pure red cell anemia (PRCA), aplastic anemia and features suggestive of myelodysplastic syndromes $[68,69]$. In a clinicopathological study of 40 SLE patients with unexplained cytopenias, BM aspirations and/or biopsies showed dyserythropoietic and dysmegakaryocytic findings in all patients, dysgranulopoiesis in 14 patients (35\%) and less than a 5\% blasts percentage in all samples [69]. More recently, in a French multicenter series of 30 active SLE patients with significant BM abnormalities after exclusion of differential diagnoses, a centralized review of BM aspirations and/or biopsies showed MDS in three patients (10\%) and that MDS features often accompanied BM fibrosis in 17 patients [70]. Moreover, similar to BM fibrosis, myelodysplastic features may regress with treatment [70-72]. However, in the absence of chromosomal or molecular abnormalities, the study proposed that the term "dysmyelopoietic" would be more appropriate than "myelodysplastic" for SLE patients because the latter term may refer to clonal disorders. Some cases reported an authentic clonal MDS in systemic lupus progressing to AML.

Less frequent CTD in the French cohort included primary antiphospholipid syndrome $(13 \%)$, myositis $(10 \%)$ and Sjogren's syndrome (6\%) [10]. No relevant cases of systemic sclerosis (SSc) were reported. Nevertheless, Ricard et al. stated a higher prevalence of clonal hematopoiesis of indeterminate potential (CHIP) in younger SSc patients $(6 / 24$, $25 \%)$ than in healthy donors $(1 / 26,4 \%)$ under 50 years, questioning the place of clonal 
hematopoiesis as the cause or consequence of a SSc-derived modified bone marrow microenvironment [73].

\subsection{Inflammatory Arthritis}

No specific rheumatologic features suggest MDS-associated arthritis and despite polyarticular symmetrical arthritis and frequent inflammatory syndrome, the presence of rheumatoid factor was relatively rare [74]. Among 68 patients with MDS-associated inflammatory arthritis reported in a multicenter retrospective study with a literature review, four rheumatologic patterns of MDS-associated arthritis were described where 21 patients (31\%) fulfilled the 1987 American College of Rheumatology (ACR) rheumatoid arthritis criteria, 18 patients $(26 \%)$ were presented as polymyalgia rheumatica-sometimes associated with giant cell arteritis $[75,76]$ — eight patients $(12 \%)$ had remitting seronegative symmetrical synovitis with pitting edema (RS3PE) syndrome and 21 patients (31\%) were presented under undifferentiated arthritis. MDS-associated arthritis frequently precedes MDS, and the possibility of inflammatory anemia could lead to the misdiagnosis of associated MDS. Undifferentiated arthritis represents the most frequent subset and typically present as polyarticular and symmetrical arthritis, usually without structural progression. In patients with polymyalgia rheumatica, a poor response to steroids or steroid dependence suggests the presence of associated MDS, particularly in the presence of cytopenia. Compared to patients without MDS, patients with polymyalgia rheumatica tended to be older and male with a more extensive joint involvement [77]. Similarly, RS3PE syndrome associated with MDS has been characterized by more frequent steroids dependence [78].

Tedeschi et al. described a case report of an older aged male patient who had been diagnosed with a de novo refractory chronic calcium pyrophosphate crystal inflammatory arthritis affecting the ankle, knee and atlanto-occipital joint (crowned dens syndrome) that developed simultaneously to an MDS with excess blasts [79].

\subsection{Skin Manifestations}

In a French monocentric prospective study of 157 patients with primary MDS followed up for a median of 44 months, the prevalence of skin manifestations were close to 10\% [80]. Skin lesions in patients with MDS include neutrophilic dermatosis such as SS and PG, leucocytoclasic vasculitis, cutaneous manifestations related to systemic diseases already mentioned (such as Behçet's-like syndrome and systemic vasculitis), and less frequently cutaneous granulomatosis [81,82]. Other skin lesions including cutaneous infections, drug adverse reactions and leukemia cutis (blastic myeloid cell infiltration of the skin) could be observed and must be distinguished from SIADs.

MDS and AML are the most frequent hematological malignancies associated with neutrophilic dermatoses [83]. Up to $20 \%$ of patients with SS and $7 \%$ of patients with PG have an underlying hematological malignancy, most commonly associated with MDS or AML [84].

SS is characterized by the sudden onset of sensitive and painful erythematous plaques, nodules, or papules with predominantly neutrophilic dermal infiltrate without vasculitis on histologic examination and with concurrent fever and arthralgia. SS presents in three clinical settings: classical (or idiopathic), malignancy-associated and drug-induced [85]. Patients with malignancy-associated SS would more likely develop extracutaneous manifestations such as pulmonary, hepatic or ocular involvement [86], and have leukopenia, whereas neutrophilia is a usual feature of classical SS. Histiocytoid SS is a histological variant of SS differing from classical neutrophilic SS by a dermal infiltrate composed of lymphocytes and immature myeloid cells (histiocytoid CD68-positive myeloperoxidasepositive mononuclear cells), and have been associated with myeloid malignancies [87-91]. As the immature skin myeloid cells seen in histiocytoid SS variants were clonally related to the myeloid malignancy using different approaches [92-96], Osio et al. proposed to designate the histiocytoid SS variant occurring in patients with MDS as "myelodysplasia cutis" [97]. 
PG is the most common neutrophilic dermatosis described in patients with MDS [98] and may present in a classical or ulcerative form with violaceous undermined borders or in atypical bullous, vegetative, or vesiculopustular variants [99]. Although histopathological features in PG are not specific, biopsy is required to confirm neutrophilic infiltration and rule out other causes of ulceration [100].

Even though cutaneous adverse events induced by azacitidine (AZA) are not entirely SIADs, they should be cited, and a distinction should be made between erythematous injection-site trivial reaction (often self-limiting without treatment) and more serious manifestations such as paradoxical neutrophilic dermatosis at injection-site (after subcutaneous injection) requiring systemic corticosteroids administration, intravenous administration of AZA or AZA discontinuation after a careful risk-benefit consideration.

\subsection{Autoimmune Cytopenias}

In 1977, Celada et al. first reported the case of a 75-year old man who developed refractory sideroblastic anemia secondary to autoimmune hemolytic anemia (AIHA), suggesting a possible association between MDS and autoimmune phenomenon [101]. According to the main series, autoimmune cytopenias have been documented in 1 to $16 \%$ of cases $[13,14,102]$. Moreover, AIHA have been reported in approximately 3\% of patients with MDS [13,103], although erythrocyte autoantibodies can be found in up to $35 \%$ of MDS patients [104].

In a cohort of $41 \mathrm{MDS} / \mathrm{CMML}$ patients with immune thrombocytopenia (ITP), defined by response to steroids, including chronic ITP in 63\%, low-risk myelodysplasia in $73 \%$ and CMML in 59\%, it was recently reported that MDS/CMML-associated ITP have a particular outcome with more severe bleeding and multi-refractory profile than primary ITP, a similar response profile to primary ITP therapy except for intravenous immunoglobulin, and less progression toward acute myeloid leukemia than MDS/CMML without ITP [105].

The main difficulty in the setting of MDS/CMML is to distinguish immune-related peripheral cytopenias from that of central origin (i.e., due to bone marrow failure). In a caseseries of five paradigmatic cases of refractory/relapsing autoimmune cytopenias (AIHA, ITP and chronic idiopathic neutropenia) that evolved to idiopathic cytopenia/dysplasia of uncertain significance (ICUS/IDUS) -two recently recognized provisional conditions characterized by isolated unexplained cytopenia / dysplasia in $<10 \%$ bone marrow cells $[106,107]$ - Barcellini et al. hypothesized a shift from autoimmunity against circulating blood cells to bone marrow precursors, leading to an insufficient marrow compensatory response, a progressive/variable degree of bone marrow dysplasia and ultimately overt bone marrow failure [108]. Furthermore, Tabata et al. reported two cases of MDS patients with AIHA in which the progression toward AML was paralleled by the disappearance of hemolysis, corroborating the possible pathogenic link between both conditions [109].

\subsection{Thrombosis}

In a French retrospective multicenter case-control study among 162 patients with MDS/CMML-associated SIADs, venous thromboembolism (VTE) occurred in 25\% of patients during a median follow-up of 14 months, including $70 \%$ of deep venous thrombosis or pulmonary embolism and $19 \%$ of patients experienced two or more VTE (unpublished personal data). The classic inherited or acquired prothrombotic risk factors, overall survival and leukemia-free survival were not significantly different in MDS/CMML-associated SIADs patients with and without VTE. In a multivariate analysis, MDS/CMML progression at VTE diagnosis was the only factor independently associated with VTE (OR 16). When patients were treated with an anticoagulation therapy, bleeding occurred in $21 \%$ of cases.

\subsection{VEXAS Syndrome}

In late 2020, Beck et al. reported that a series of 25 cases of older aged male adults had characteristic late-onset severe treatment-refractory inflammatory disease associated with hematological abnormalities named VEXAS syndrome (vacuoles, E1 enzyme, Xlinked, autoinflammatory, somatic) that were caused by somatic mutations of methionine- 
41 (p.Met41) in Ubiquitin-like modifier activating enzyme 1 (UBA1) gene that encodes ubiquitylation-initiating E1 enzyme and is located on the X chromosome [110]. Clinical phenotype included recurrent fever, neutrophilic cutaneous and pulmonary inflammation, ear and nose chondritis, vasculitis, venous thromboembolism, cytopenias especially macrocytic anemia, characteristic vacuoles in myeloid and erythroid precursor cells and dysplastic bone marrow. Most of the patients met diagnostic or classification criteria for various inflammatory syndromes including polyarteritis nodosa, SS and relapsing polychondritis, and/or non-benign hematologic conditions (multiple myeloma or myelodysplastic syndrome) or both. Subsequently, Obiorah et al. reported a series of 15 other male patients with VEXAS syndrome and peripheral cytopenias, 10 of which had myeloid or lymphoid clonal disease (MDS, plasma cell dyscrasias, and monoclonal B cell lymphocytosis) [111]. A patient with VEXAS syndrome presented unusual infectious complications, also suggesting a possible acquired immune deficiency in this syndrome [112].

\subsection{Other Manifestations}

Various other systemic or organ specific diseases have been reported in MDS patients, including secondary pulmonary alveolar proteinosis (PAP), which is a rare syndrome that predominantly affects the lungs, and is characterized by the accumulation of surfactant lipids and proteins in the alveoli and terminal airways. Among secondary PAP (not associated with granulocyte-macrophage colony-stimulating factor (GM-CSF) autoantibodies) representing $10 \%$ of all PAP cases and associated with a very poor prognosis (median survival time of $<20$ months), myelodysplastic syndrome accounted for $65 \%$ of underlying conditions [113].

Few cases of inflammatory bowel disease, especially Crohn disease with an unusually high frequency of colorectal involvement, was also reported with MDS patients [114].

Besides well-defined inflammatory diseases, many patients with MDS have undifferentiated autoinflammatory syndrome (UAD) defined by the presence of non-specific symptoms such as recurrent fever, arthralgia, myalgia, skin rash, arthritis and pleuritic, peritonitis in association with persistently elevated CRP that cannot be attributed to infection. In a cohort of 62 MDS patients with autoinflammatory complications, Watad et al. found that $84 \%$ of patients had UAD [52]. Their study also linked MDS-related autoinflammation to karyotype abnormalities (OR 2.76) and somatic mutations (OR 2.2), particularly RUNX1, BCOR, WTI and TP53. In their findings, it was shown that inflammatory disorders within the MDS spectrum were more strongly associated with autoinflammatory conditions than autoimmune diseases, which was unsurprising given that disorders were collectively linked to dysfunction of myeloid cells that are key players in the innate immune system.

\section{Laboratory Immune Abnormalities in MDS Patients with and without Clinical SIADs}

Fraison et al. analyzed the prevalence of various autoantibodies in MDS/CMML patients with and without associated SIADs [115]. In MDS patients without SIADS, autoantibodies were found in 50\% of MDS patients without SIADs: $20 \%$ of which had anti-nuclear antibodies (ANA), $6 \%$ with anti-DNA antibodies, $4 \%$ with anti-ENA antibodies, $15 \%$ with antiphospholipid antibodies, $9 \%$ with anti-neutrophils cytoplasm antibodies (ANCA) without anti-PR3 or anti-MPO specificity, $12 \%$ with rheumatoid factor, $3 \%$ with anti-citrullinated peptide antibodies (ACPA) and $12 \%$ with anti-tissue antibodies. CMML patients displayed higher frequencies of ANCA and antiphospholipid antibodies than MDS patients. ANCA were reported in up to $5 \%$ of MDS patients compared to $2 \%$ in lymphoid malignancies and $0-1.8 \%$ in controls [17]. Interestingly, no differences were found in the frequencies of various autoantibodies in MDS/CMML patients with and without associated SIADs. As already discussed previously, this could be primarily explained by the reasoning that contrary to idiopathic autoimmune diseases, MDS-related SIADs involve autoinflammatory mechanisms rather than autoimmune. Thus, autoantibodies screening remains negative or clinically irrelevant in most cases. 


\section{Prognosis}

The prognostic significance of MDS-associated SIADs remains controversial. In 123 patients with SIADs and MDS/CMML, compared to 665 MDS/CMML patients, median overall survival was not significantly different (72 and 75 months, respectively), with similar rates of acute myeloid leukemia (22\% and $21 \%$, respectively) and deaths ( $44 \%$ and $48 \%$, respectively) during a median follow-up of 25 months. Similarly, no difference in overall survival were shown in the study by De Hollanda et al., except a possible negative prognosis in the presence of systemic vasculitis or cryoglobulinemia [11]. In another prospective study of 70 patients, median overall survival was 39 months in MDS-related SIADs patients $(n=13)$ versus 26 months $(n=57)$ in MDS patients [15]. Conversely, some authors showed that the presence of MDS/CMML-associated SIADs was associated with better overall survival $[13,14]$ while others remarked the association with poorer survival [116-119]. The heterogeneity of these results was possibly due to a great diversity of immune manifestations, median age of patients, percentage of MDS/CMML subtypes, the follow-up and study periods reflecting the change of WHO classifications and therapeutic progress over, and biases related to the retrospective nature of the majority of the studies. It may be worth noting that all of the largest reported studies suggested either a beneficial effect or a lack of impact in overall mortality. In the same way and for the same reasons, the rate of AML transformation was not equivocal between different studies.

\section{Treatment of MDS-Related SIADs}

Treatment of MDS-related SIADs can be challenging because of the underlying cytopenias, the risk of infectious complications and the risk of secondary MDS with certain immunosuppressive treatments [120]. Therapeutic indications and treatment regimens must take account of the subtype, severity and relapse rates of SIADs, and the need for specific hematological treatment for underlying MDS/CMML.

\subsection{Systemic Glucocorticoids}

In first-line treatment, glucocorticoids are the most used drugs and induce remission in 80 to $90 \%$ of cases $[9,10]$. However, despite initial efficacy, steroid dependence or relapse occurs in 50 to $70 \%$ of cases, justifying the use of second-line treatment for which only $60 \%$ of patients will have a sustained response [10].

\subsection{Conventional Synthetic and Biological DMARDs}

In steroid-dependent or refractory patients or life-threatening disease at onset, immunosuppressive or immunomodulating drugs including conventional synthetic DMARDs (methotrexate, azathioprine, mycophenolate mofetil and cyclophosphamide), biological targeting agents (rituximab, anti-TNF- $\alpha$, tocilizumab and anakinra) should be considered. It is to highlight that the hematological toxicity of methotrexate, azathioprine and cyclophosphamide may limit their use in this context of myeloid neoplasms.

Few reports showed efficacy of biological targeting drugs, however in a French study of $29 \mathrm{MDS} / \mathrm{CMML}$ patients with SIADs, biological targeted drugs have shown poor efficacy to induce clinical remission [121]. Considering all 114 lines of treatments, overall response (in other words complete or partial) occurred for $31 \%$ of patients with TNF- $\alpha$ antagonists, $25 \%$ anakinra, $33 \%$ tocilizumab and $58 \%$ with rituximab. Comparing response rates to that with steroids, clinical remission was lower with DMARDs, TNF- $\alpha$ antagonists and anakinra (HR 0.18, 0.17 and 0.26 , respectively) but did not differ for rituximab and azacitidine (HR 0.49 and 0.4 , respectively). Regarding safety, biological-targeted drugs in MDS patients have been associated with high rates of severe infections (a total of 30 infections in 18 out of 29 patients) during a three-year median follow-up.

\subsection{Other Treatments (IMiDs, Low Dose Interleukin-2, JAK Inhibitors)}

Efficacy of immunomodulatory imide drugs (IMiDs) such as thalidomide or lenalidomide, were reported for the treatment of neutrophilic dermatoses such as SS or PG in 
patients with MDS. However, lenalidomide has been described as a potential trigger of SS in some patients with MDS [122-124].

Colchicine or dapsone could be used during mild forms of isolated leukocytoclastic vasculitis.

Due to its ability to activate and expand regulatory T-cell without activating effector $T$ cells in various autoimmune and inflammatory diseases $[125,126]$, the use of low dose interleukin-2 (ld-IL-2) in association with AZA was safe and allowed, at least temporarily, steroid-sparing effects, without inducing any progression of the MDS in two out of the three patients with dysimmune features associated with MDS [127].

Efficacy of JAK inhibition was reported during the inflammation associated with primary myelofibrosis, graft-versus-host disease and others immune-inflammatory diseases [128-130]. Results were found with JAK inhibitors during VEXAS syndrome, subject to retrospective small cohort study with short duration of follow-up [131], and needs to be evaluated prospectively.

\subsection{Hypomethylating Agents (HMAs)}

In patients with higher-risk MDS without major comorbidities who are not immediately eligible for allogenic stem cell transplantation (SCT), AZA is recommended as the first-line reference treatment [132].

AZA efficacy in MDS-related SIADs was reported in few case reports, mainly with refractory MDS-related SIADs, including neutrophilic dermatosis, SLE, inflammatory bowel diseases, polyarthritis, vasculitis and relapsing polychondritis [133-139].

In addition to its direct action on the tumor clone in a context of paraneoplastic syndrome, the potential efficacy of hypomethylating agents in inflammatory or autoimmune disorders associated with MDS may be supported by immunomodulatory effects on various immune cells as CD4+ T-cells including Treg lymphocytes [135,140,141], especially in the context of post-allogenic SCT [142], NK cells [143-145], dendritic cells [146], myeloidderived suppressor cells (MDSCs) [147] and pro-inflammatory cytokines modulation, in particular IL-6 [148].

In the largest available retrospective study, the efficacy of AZA was reported in 22 MDS/CMML patients with concomitant SIADs, half of whom with low or int-1 IPSS and the other half with int-2 or high-IPSS [149]. AZA was initiated for transfusion dependence, severe thrombocytopenia or refractory SIADs in lower-risk MDS, and according to the drug label in higher-risk MDS. At AZA onset, 15 patients had uncontrolled SIADs. Response of SIADs to AZA was observed in 19 patients $(86 \%)$ and reduction or discontinuation of steroids and/or immunosuppressive therapy was possible in 16 cases $(73 \%)$. The change in MDS/CMML and SIADs was parallel in 13 cases (59\%), being both favorable in 11 cases and both unfavorable in two cases. All responses of SIADs to AZA were seen by the third cycle, although about one third of responses improved and became complete between three and six cycles. Furthermore, although less than $50 \%$ of the patients received more than six cycles of AZA, only three relapses of SIADs were observed after three, 19 and 19 months, respectively. To confirm these preliminary data, an ongoing phase II trial is currently assessing the efficacy and safety of AZA in patients with MDS/CMML and steroid-dependent or resistant SIADs (NCT02985190) on behalf of the French MDS network (Groupe Francophone des Myélodysplasies, GFM) and the French Network of dysimmune disorders associated with hemopathies (MINHEMON).

\subsection{Bone Marrow Engraftment}

Few studies report cases of severe or refractory inflammatory or autoimmune diseases in response after hematopoietic SCT, whether in MDS-related context [150-156] or not $[157,158]$. Similar to what was reported for AZA, the resolution of SIADs after SCT was almost always associated with the efficacy of transplantation towards the MDS clone. 


\section{Conclusions and Perspectives}

Systemic inflammatory and autoimmune disorders develop in up to a quarter of MDS/CMML patients with various subtypes and sometimes in unclassified forms. The understanding of common pathways linking MDS and autoimmunity are growing with identification of deregulation in innate and adaptive immune cells, cytokine secretion and genetic landscape underlying MDS. Recent advances in the field of clonal hematopoiesis are opening new pathophysiological perspectives, bringing together the concepts of somatic mutations, myeloid cell dysfunction, innate immunity deregulation and auto-inflammation, suggesting that some of these disorders could be borderline between clonal and inflammatory phenomena.

Although the presence of SIADs does not impact neither overall survival nor disease progression to AML, they can make therapy challenging when it comes to avoiding steroid dependence and associated adverse events of immunosuppressive drugs. Increasing evidence suggests that MDS specific therapy such as AZA, particularly through its immunomodulatory effect, may be effective in treating patients with SIADs and sparing steroids concomitantly to MDS disease control. Prospective studies should be conducted to address the place of AZA in such situations and to help physicians in choosing the best therapeutic strategy.

Author Contributions: Conceptualization, A.M., P.F., O.F.; methodology, V.J., A.M.; validation, V.J., P.F., A.S., Y.H., L.A., O.F. and A.M.; investigation, V.J.; writing—original draft preparation, V.J.; writing-review and editing, A.M.; supervision, A.M., O.F. All authors have read and agreed to the published version of the manuscript.

Funding: This research received no external funding.

Institutional Review Board Statement: Not applicable.

Informed Consent Statement: Not applicable.

Data Availability Statement: Data sharing was not applicable to this research as no datasets were generated or analyzed during the course of the study.

Acknowledgments: The authors would like to thank Sarina Yaghobian from AcaciaTools for reviewing the manuscript.

Conflicts of Interest: A.M. is an investigator of CELGENE, ROCHE, CHUGAI founded trials with APHP and Hopital 15-20 promotion; A.M. received several fees for congress travels and expert use from LFB, SANOFI, SHIRE, and CELGENE. All the other authors declare no conflict of interest.

\section{References}

1. Adès, L.; Itzykson, R.; Fenaux, P. Myelodysplastic syndromes. Lancet 2014, 383, 2239-2252. [CrossRef]

2. Bejar, R.; Stevenson, K.; Abdel-Wahab, O.; Galili, N.; Nilsson, B.; Garcia-Manero, G.; Kantarjian, H.; Raza, A.; Levine, R.L.; Neuberg, D.; et al. Clinical effect of point mutations in myelodysplastic syndromes. N. Engl. J. Med. 2011, 364, $2496-2506$. [CrossRef] [PubMed]

3. Yang, L.; Qian, Y.; Eksioglu, E.; Epling-Burnette, P.K.; Wei, S. The inflammatory microenvironment in MDS. Cell. Mol. Life Sci. 2015, 72, 1959-1966. [CrossRef]

4. Shen, J.; Wang, S.; Zhang, Y.-J.; Kappil, M.A.; Chen Wu, H.; Kibriya, M.G.; Wang, Q.; Jasmine, F.; Ahsan, H.; Lee, P.-H.; et al. Genome-wide aberrant DNA methylation of microRNA host genes in hepatocellular carcinoma. Epigenetics 2012, 7, $1230-1237$. [CrossRef] [PubMed]

5. Jiang, Y.; Dunbar, A.; Gondek, L.P.; Mohan, S.; Rataul, M.; O’Keefe, C.; Sekeres, M.; Saunthararajah, Y.; Maciejewski, J.P. Aberrant DNA methylation is a dominant mechanism in MDS progression to AML. Blood 2009, 113, 1315-1325. [CrossRef] [PubMed]

6. Bacher, U.; Shumilov, E.; Flach, J.; Porret, N.; Joncourt, R.; Wiedemann, G.; Fiedler, M.; Novak, U.; Amstutz, U.; Pabst, T. Challenges in the introduction of next-generation sequencing (NGS) for diagnostics of myeloid malignancies into clinical routine use. Blood Cancer J. 2018, 8, 113. [CrossRef]

7. Mufti, G.J.; Figes, A.; Hamblin, T.J.; Oscier, D.G.; Copplestone, J.A. Immunological abnormalities in myelodysplastic syndromes. I. Serum immunoglobulins and autoantibodies. Br. J. Haematol. 1986, 63, 143-147. [CrossRef]

8. Saif, M.W.; Hopkins, J.L.; Gore, S.D. Autoimmune phenomena in patients with myelodysplastic syndromes and chronic myelomonocytic leukemia. Leuk. Lymphoma 2002, 43, 2083-2092. [CrossRef] 
9. Enright, H.; Miller, W. Autoimmune phenomena in patients with myelodysplastic syndromes. Leuk. Lymphoma 1997, 24, 483-489. [CrossRef]

10. Mekinian, A.; Grignano, E.; Braun, T.; Decaux, O.; Liozon, E.; Costedoat-Chalumeau, N.; Kahn, J.-E.; Hamidou, M.; Park, S.; Puéchal, X.; et al. Systemic inflammatory and autoimmune manifestations associated with myelodysplastic syndromes and chronic myelomonocytic leukaemia: A French multicentre retrospective study. Rheumatology 2016, 55, 291-300. [CrossRef]

11. de Hollanda, A.; Beucher, A.; Henrion, D.; Ghali, A.; Lavigne, C.; Lévesque, H.; Hamidou, M.; Subra, J.F.; Ifrah, N.; Belizna, C. Systemic and immune manifestations in myelodysplasia: A multicenter retrospective study. Arthritis Care Res. (Hoboken) 2011, 63, 1188-1194. [CrossRef] [PubMed]

12. Marisavljević, D.; Kraguljac, N.; Rolović, Z. Immunologic abnormalities in myelodysplastic syndromes: Clinical features and characteristics of the lymphoid population. Med. Oncol. 2006, 23, 385-391. [CrossRef]

13. Komrokji, R.S.; Kulasekararaj, A.; Al Ali, N.H.; Kordasti, S.; Bart-Smith, E.; Craig, B.M.; Padron, E.; Zhang, L.; Lancet, J.E.; Pinilla-Ibarz, J.; et al. Autoimmune diseases and myelodysplastic syndromes. Am. J. Hematol. 2016, 91, E280-E283. [CrossRef] [PubMed]

14. Seguier, J.; Gelsi-Boyer, V.; Ebbo, M.; Hamidou, Z.; Charbonnier, A.; Bernit, E.; Durand, J.-M.; Harlé, J.-R.; Vey, N.; Schleinitz, $\mathrm{N}$. Autoimmune diseases in myelodysplastic syndrome favors patients survival: A case control study and literature review. Autoimmun. Rev. 2019, 18, 36-42. [CrossRef] [PubMed]

15. Giannouli, S.; Voulgarelis, M.; Zintzaras, E.; Tzioufas, A.G.; Moutsopoulos, H.M. Autoimmune phenomena in myelodysplastic syndromes: A 4-yr prospective study. Rheumatology (Oxford) 2004, 43, 626-632. [CrossRef] [PubMed]

16. Berthier, S.; Magy, N.; Gil, H.; Schneider, M.B.; Vuitton, D.A.; Dupond, J.L. Myelodysplasias and systemic diseases. A nonfortuitous association. Rev. Med. Interne 2001, 22, 428-432. [CrossRef]

17. Hamidou, M.A.; Derenne, S.; Audrain, M.A.; Berthelot, J.M.; Boumalassa, A.; Grolleau, J.Y. Prevalence of rheumatic manifestations and antineutrophil cytoplasmic antibodies in haematological malignancies. A prospective study. Rheumatology (Oxford) 2000, 39, 417-420. [CrossRef] [PubMed]

18. Anderson, L.A.; Pfeiffer, R.M.; Landgren, O.; Gadalla, S.; Berndt, S.I.; Engels, E.A. Risks of myeloid malignancies in patients with autoimmune conditions. Br. J. Cancer 2009, 100, 822-828. [CrossRef]

19. Kristinsson, S.Y.; Björkholm, M.; Hultcrantz, M.; Derolf, Å.R.; Landgren, O.; Goldin, L.R. Chronic Immune Stimulation Might Act As a Trigger for the Development of Acute Myeloid Leukemia or Myelodysplastic Syndromes. J. Clin. Oncol. 2011, 29, $2897-2903$. [CrossRef]

20. Dalamaga, M.; Petridou, E.; Cook, F.E.; Trichopoulos, D. Risk factors for myelodysplastic syndromes: A case-control study in Greece. Cancer Causes Control 2002, 13, 603-608. [CrossRef] [PubMed]

21. Braun, T.; Fenaux, P. Myelodysplastic Syndromes (MDS) and autoimmune disorders (AD): Cause or consequence? Best Pract. Res. Clin. Haematol. 2013, 26, 327-336. [CrossRef]

22. Parker, J.E.; Mufti, G.J. Excessive apoptosis in low risk myelodysplastic syndromes (MDS). Leuk. Lymphoma 2000, 40, 1-24. [CrossRef] [PubMed]

23. Zeng, W.; Miyazato, A.; Chen, G.; Kajigaya, S.; Young, N.S.; Maciejewski, J.P. Interferon-gamma-induced gene expression in CD34 cells: Identification of pathologic cytokine-specific signature profiles. Blood 2006, 107, 167-175. [CrossRef]

24. Kitagawa, M.; Saito, I.; Kuwata, T.; Yoshida, S.; Yamaguchi, S.; Takahashi, M.; Tanizawa, T.; Kamiyama, R.; Hirokawa, K. Overexpression of tumor necrosis factor (TNF)-alpha and interferon (IFN)-gamma by bone marrow cells from patients with myelodysplastic syndromes. Leukemia 1997, 11, 2049-2054. [CrossRef] [PubMed]

25. Gañán-Gómez, I.; Wei, Y.; Starczynowski, D.T.; Colla, S.; Yang, H.; Cabrero-Calvo, M.; Bohannan, Z.S.; Verma, A.; Steidl, U.; Garcia-Manero, G. Deregulation of innate immune and inflammatory signaling in myelodysplastic syndromes. Leukemia 2015, 29, 1458-1469. [CrossRef]

26. Claessens, Y.-E.; Bouscary, D.; Dupont, J.-M.; Picard, F.; Melle, J.; Gisselbrecht, S.; Lacombe, C.; Dreyfus, F.; Mayeux, P.; FontenayRoupie, M. In vitro proliferation and differentiation of erythroid progenitors from patients with myelodysplastic syndromes: Evidence for Fas-dependent apoptosis. Blood 2002, 99, 1594-1601. [CrossRef] [PubMed]

27. Maciejewski, J.P.; Selleri, C.; Sato, T.; Anderson, S.; Young, N.S. Increased expression of Fas antigen on bone marrow CD34+ cells of patients with aplastic anaemia. Br. J. Haematol. 1995, 91, 245-252. [CrossRef] [PubMed]

28. Baumann, I.; Scheid, C.; Koref, M.S.; Swindell, R.; Stern, P.; Testa, N.G. Autologous lymphocytes inhibit hemopoiesis in long-term culture in patients with myelodysplastic syndrome. Exp. Hematol. 2002, 30, 1405-1411. [CrossRef]

29. Zheng, Z.; Qianqiao, Z.; Qi, H.; Feng, X.; Chunkang, C.; Xiao, L. In vitro deprivation of CD8(+)CD57(+)T cells promotes the malignant growth of bone marrow colony cells in patients with lower-risk myelodysplastic syndrome. Exp. Hematol. 2010, 38, 677-684. [CrossRef] [PubMed]

30. Sloand, E.M.; Melenhorst, J.J.; Tucker, Z.C.G.; Pfannes, L.; Brenchley, J.M.; Yong, A.; Visconte, V.; Wu, C.; Gostick, E.; Scheinberg, P.; et al. T-cell immune responses to Wilms tumor 1 protein in myelodysplasia responsive to immunosuppressive therapy. Blood 2011, 117, 2691-2699. [CrossRef] [PubMed]

31. Kordasti, S.Y.; Ingram, W.; Hayden, J.; Darling, D.; Barber, L.; Afzali, B.; Lombardi, G.; Wlodarski, M.W.; Maciejewski, J.P.; Farzaneh, F.; et al. CD4+CD25high Foxp3+ regulatory T cells in myelodysplastic syndrome (MDS). Blood 2007, 110, 847-850. [CrossRef] 
32. Kordasti, S.Y.; Afzali, B.; Lim, Z.; Ingram, W.; Hayden, J.; Barber, L.; Matthews, K.; Chelliah, R.; Guinn, B.; Lombardi, G.; et al. IL-17-producing CD4(+) T cells, pro-inflammatory cytokines and apoptosis are increased in low risk myelodysplastic syndrome. Br. J. Haematol. 2009, 145, 64-72. [CrossRef] [PubMed]

33. Hamdi, W.; Ogawara, H.; Handa, H.; Tsukamoto, N.; Nojima, Y.; Murakami, H. Clinical significance of regulatory T cells in patients with myelodysplastic syndrome. Eur. J. Haematol. 2009, 82, 201-207. [CrossRef] [PubMed]

34. Aggarwal, N.; Swerdlow, S.H.; TenEyck, S.P.; Boyiadzis, M.; Felgar, R.E. Natural killer cell (NK) subsets and NK-like T-cell populations in acute myeloid leukemias and myelodysplastic syndromes. Cytom. B Clin. Cytom. 2016, 90, 349-357. [CrossRef] [PubMed]

35. Sawanobori, M.; Yamaguchi, S.; Hasegawa, M.; Inoue, M.; Suzuki, K.; Kamiyama, R.; Hirokawa, K.; Kitagawa, M. Expression of TNF receptors and related signaling molecules in the bone marrow from patients with myelodysplastic syndromes. Leuk. Res. 2003, 27, 583-591. [CrossRef]

36. Epling-Burnette, P.K.; Painter, J.S.; Rollison, D.E.; Ku, E.; Vendron, D.; Widen, R.; Boulware, D.; Zou, J.X.; Bai, F.; List, A.F. Prevalence and clinical association of clonal T-cell expansions in Myelodysplastic Syndrome. Leukemia 2007, 21, 659-667. [CrossRef] [PubMed]

37. Kotsianidis, I.; Bouchliou, I.; Nakou, E.; Spanoudakis, E.; Margaritis, D.; Christophoridou, A.V.; Anastasiades, A.; Tsigalou, C.; Bourikas, G.; Karadimitris, A.; et al. Kinetics, function and bone marrow trafficking of CD4+CD25+FOXP3+ regulatory T cells in myelodysplastic syndromes (MDS). Leukemia 2009, 23, 510-518. [CrossRef] [PubMed]

38. Mailloux, A.W.; Sugimori, C.; Komrokji, R.S.; Yang, L.; Maciejewski, J.P.; Sekeres, M.A.; Paquette, R.; Loughran, T.P.; List, A.F.; Epling-Burnette, P.K. Expansion of effector memory regulatory T cells represents a novel prognostic factor in lower risk myelodysplastic syndrome. J. Immunol. 2012, 189, 3198-3208. [CrossRef] [PubMed]

39. Hejazi, M.; Manser, A.R.; Fröbel, J.; Kündgen, A.; Zhao, X.; Schönberg, K.; Germing, U.; Haas, R.; Gattermann, N.; Uhrberg, M. Impaired cytotoxicity associated with defective natural killer cell differentiation in myelodysplastic syndromes. Haematologica 2015, 100, 643-652. [CrossRef] [PubMed]

40. Jiang, H.; Fu, R.; Wang, H.; Li, L.; Qu, W.; Liang, Y.; Wang, G.; Wang, X.; Wu, Y.-H.; Liu, H.; et al. Increased circulating of myeloid-derived suppressor cells in myelodysplastic syndrome. Chin. Med. J. (Engl.) 2013, 126, 2582-2584. [PubMed]

41. Chen, X.; Eksioglu, E.A.; Zhou, J.; Zhang, L.; Djeu, J.; Fortenbery, N.; Epling-Burnette, P.; Van Bijnen, S.; Dolstra, H.; Cannon, J.; et al. Induction of myelodysplasia by myeloid-derived suppressor cells. J. Clin. Investig. 2013, 123, 4595-4611. [CrossRef]

42. Giannouli, S.; Tzoanopoulos, D.; Ritis, K.; Kartalis, G.; Moutsopoulos, H.M.; Voulgarelis, M. Autoimmune manifestations in human myelodysplasia: A positive correlation with interferon regulatory factor-1 (IRF-1) expression. Ann. Rheum. Dis. 2004, 63, 578-582. [CrossRef] [PubMed]

43. Kiladjian, J.-J.; Visentin, G.; Viey, E.; Chevret, S.; Eclache, V.; Stirnemann, J.; Bourhis, J.H.; Chouaib, S.; Fenaux, P.; Caignard, A. Activation of cytotoxic T-cell receptor gammadelta $\mathrm{T}$ lymphocytes in response to specific stimulation in myelodysplastic syndromes. Haematologica 2008, 93, 381-389. [CrossRef] [PubMed]

44. Fuster, J.J.; MacLauchlan, S.; Zuriaga, M.A.; Polackal, M.N.; Ostriker, A.C.; Chakraborty, R.; Wu, C.-L.; Sano, S.; Muralidharan, S.; Rius, C.; et al. Clonal hematopoiesis associated with TET2 deficiency accelerates atherosclerosis development in mice. Science 2017, 355, 842-847. [CrossRef] [PubMed]

45. Zhang, Q.; Zhao, K.; Shen, Q.; Han, Y.; Gu, Y.; Li, X.; Zhao, D.; Liu, Y.; Wang, C.; Zhang, X.; et al. Tet2 is required to resolve inflammation by recruiting Hdac2 to specifically repress IL-6. Nature 2015, 525, 389-393. [CrossRef]

46. Yue, X.; Trifari, S.; Äijö, T.; Tsagaratou, A.; Pastor, W.A.; Zepeda-Martínez, J.A.; Lio, C.-W.J.; Li, X.; Huang, Y.; Vijayanand, P.; et al. Control of Foxp3 stability through modulation of TET activity. J. Exp. Med. 2016, 213, 377-397. [CrossRef]

47. Ichiyama, K.; Chen, T.; Wang, X.; Yan, X.; Kim, B.-S.; Tanaka, S.; Ndiaye-Lobry, D.; Deng, Y.; Zou, Y.; Zheng, P.; et al. The methylcytosine dioxygenase Tet2 promotes DNA demethylation and activation of cytokine gene expression in T cells. Immunity 2015, 42, 613-626. [CrossRef]

48. Mundle, S.D.; Venugopal, P.; Cartlidge, J.D.; Pandav, D.V.; Broady-Robinson, L.; Gezer, S.; Robin, E.L.; Rifkin, S.R.; Klein, M.; Alston, D.E.; et al. Indication of an involvement of interleukin-1 beta converting enzyme-like protease in intramedullary apoptotic cell death in the bone marrow of patients with myelodysplastic syndromes. Blood 1996, 88, 2640-2647. [CrossRef] [PubMed]

49. Miyoshi, T.; Yamashita, K.; Ohno, T.; Izumi, T.; Takaori-Kondo, A.; Sasada, M.; Uchiyama, T. Familial Mediterranean fever gene as a possible modifier of Sweet syndrome with chronic myelogenous leukemia. Acta Haematol. 2008, 120, 57-62. [CrossRef]

50. Jo, T.; Horio, K.; Migita, K. Sweet's syndrome in patients with MDS and MEFV mutations. N. Engl. J. Med. 2015, 372, 686-688. [CrossRef]

51. Wolach, O.; Stone, R. Autoimmunity and Inflammation in Myelodysplastic Syndromes. Acta Haematol. 2016, 136, 108-117. [CrossRef] [PubMed]

52. Watad, A.; Kacar, M.; Bragazzi, N.L.; Zhou, Q.; Jassam, M.; Taylor, J.; Roman, E.; Smith, A.; Jones, R.A.; Amital, H.; et al. Somatic Mutations and the Risk of Undifferentiated Autoinflammatory Disease in MDS: An Under-Recognized but Prognostically Important Complication. Front. Immunol. 2021, 12, 610019. [CrossRef]

53. Hamidou, M.A.; Boumalassa, A.; Larroche, C.; El Kouri, D.; Blétry, O.; Grolleau, J.Y. Systemic medium-sized vessel vasculitis associated with chronic myelomonocytic leukemia. Semin. Arthritis Rheum. 2001, 31, 119-126. [CrossRef] [PubMed] 
54. Grignano, E.; Mekinian, A.; Braun, T.; Liozon, E.; Hamidou, M.; Decaux, O.; Puéchal, X.; Kahn, J.E.; Schoindre, Y.; Rossignol, J.; et al. Autoimmune and inflammatory diseases associated with chronic myelomonocytic leukemia: A series of 26 cases and literature review. Leuk. Res. 2016, 47, 136-141. [CrossRef] [PubMed]

55. Wesner, N.; Drevon, L.; Guedon, A.; Fraison, J.B.; Terrier, B.; Trad, S.; Kahn, J.E.; Aouba, A.; Gillard, J.; Ponsoye, M.; et al. Gastrointestinal Behcet's-like disease with myelodysplastic neoplasms with trisomy 8: A French case series and literature review. Leuk. Lymphoma 2019, 60, 1782-1788. [CrossRef] [PubMed]

56. Fujiwara, D.; Hamada, T.; Yamasaki, O.; Sando, Y.; Saeki, K.; Fujii, N.; Kawakami, Y.; Iwatsuki, K. Successful use of etoposide for pyoderma gangrenosum associated with myelodysplastic syndrome and trisomy 8: Cytokine profiles during treatment. Eur. J. Dermatol. 2017, 27, 525-527. [CrossRef] [PubMed]

57. Hattori, H.; Hoshida, S.; Yoneda, S. Sweet's syndrome associated with recurrent fever in a patient with trisomy 8 myelodysplastic syndrome. Int. J. Hematol. 2003, 77, 383-386. [CrossRef]

58. Nishida, A.; Miyamoto, A.; Yamamaoto, H.; Uchida, N.; Izutsu, K.; Wake, A.; Ohta, Y.; Fujii, T.; Araoka, H.; Taniguchi, S.; et al. Possible association of trisomy 8 with secondary pulmonary alveolar proteinosis in myelodysplastic syndrome. Am. J. Respir. Crit. Care Med. 2011, 184, 279-280. [CrossRef]

59. Wesner, N.; Drevon, L.; Guedon, A.; Fraison, J.B.; Trad, S.; Kahn, J.E.; Aouba, A.; Gillard, J.; Ponsoye, M.; Hanslik, T.; et al. Inflammatory disorders associated with trisomy 8-myelodysplastic syndromes: French retrospective case-control study. Eur. J. Haematol. 2019, 102, 63-69. [CrossRef]

60. Zhao, L.-P.; Boy, M.; Azoulay, C.; Clappier, E.; Sébert, M.; Amable, L.; Klibi, J.; Benlagha, K.; Espéli, M.; Balabanian, K.; et al. Genomic landscape of MDS/CMML associated with systemic inflammatory and autoimmune disease. Leukemia 2021. [CrossRef]

61. Oh, Y.-J.; Shin, D.-Y.; Hwang, S.M.; Kim, S.-M.; Im, K.; Park, H.S.; Kim, J.-A.; Song, Y.W.; Márquez, A.; Martín, J.; et al. Mutation of ten-eleven translocation-2 is associated with increased risk of autoimmune disease in patients with myelodysplastic syndrome. Korean J. Intern. Med. 2020, 35, 457-464. [CrossRef]

62. Roupie, A.L.; Guedon, A.; Terrier, B.; Lahuna, C.; Jachiet, V.; Regent, A.; de Boysson, H.; Carrat, F.; Seguier, J.; Terriou, L.; et al. Vasculitis associated with myelodysplastic syndrome and chronic myelomonocytic leukemia: French multicenter case-control study. Semin. Arthritis Rheum. 2020, 50, 879-884. [CrossRef] [PubMed]

63. Roupie, A.L.; de Boysson, H.; Thietart, S.; Carrat, F.; Seguier, J.; Terriou, L.; Versini, M.; Queyrel, V.; Groh, M.; Benhamou, Y.; et al. Giant-cell arteritis associated with myelodysplastic syndrome: French multicenter case control study and literature review. Autoimmun. Rev. 2020, 19, 102446. [CrossRef] [PubMed]

64. Dion, J.; Costedoat-Chalumeau, N.; Sène, D.; Cohen-Bittan, J.; Leroux, G.; Dion, C.; Francès, C.; Piette, J.-C. Relapsing Polychondritis Can Be Characterized by Three Different Clinical Phenotypes: Analysis of a Recent Series of 142 Patients. Arthritis Rheumatol. 2016, 68, 2992-3001. [CrossRef] [PubMed]

65. Francès, C.; el Rassi, R.; Laporte, J.L.; Rybojad, M.; Papo, T.; Piette, J.C. Dermatologic manifestations of relapsing polychondritis. A study of 200 cases at a single center. Medicine (Baltimore) 2001, 80, 173-179. [CrossRef] [PubMed]

66. Myers, B.; Gould, J.; Dolan, G. Relapsing polychondritis and myelodysplasia: A report of two cases and review of the current literature. Clin. Lab. Haematol. 2000, 22, 45-48. [CrossRef] [PubMed]

67. Piette, J.C.; Papo, T.; Chavanon, P.; Huong, D.L.; Frances, C.; Godeau, P. Myelodysplasia and relapsing polychondritis. J. Rheumatol. 1995, 22, 1208-1209. [PubMed]

68. Lu, M.; Bernatsky, S.; Ramsey-Goldman, R.; Petri, M.; Manzi, S.; Urowitz, M.B.; Gladman, D.; Fortin, P.R.; Ginzler, E.M.; Yelin, E.; et al. Non-lymphoma hematological malignancies in systemic lupus erythematosus. Oncology 2013, 85, 235-240. [CrossRef]

69. Voulgarelis, M.; Giannouli, S.; Tasidou, A.; Anagnostou, D.; Ziakas, P.D.; Tzioufas, A.G. Bone marrow histological findings in systemic lupus erythematosus with hematologic abnormalities: A clinicopathological study. Am. J. Hematol. 2006, 81, 590-597. [CrossRef]

70. Chalayer, E.; Costedoat-Chalumeau, N.; Beyne-Rauzy, O.; Ninet, J.; Durupt, S.; Tebib, J.; Asli, B.; Lambotte, O.; Ffrench, M.; Vasselon, C.; et al. Bone marrow involvement in systemic lupus erythematosus. QJM 2017, 110, 701-711. [CrossRef] [PubMed]

71. Simonetta, F.; Posa, M.; Villard, J.; Marceau-Renaut, A.; Preudhomme, C.; Samii, K.; Chizzolini, C. Restoration of hematopoiesis in a case of myelodysplastic syndrome associated with systemic lupus erythematosus treated with rituximab. Ann. Hematol. 2015, 94, 1247-1249. [CrossRef] [PubMed]

72. Oka, Y.; Kameoka, J.; Hirabayashi, Y.; Takahashi, R.; Ishii, T.; Sasaki, T.; Harigae, H. Reversible bone marrow dysplasia in patients with systemic lupus erythematosus. Intern. Med. 2008, 47, 737-742. [CrossRef] [PubMed]

73. Ricard, L.; Hirsch, P.; Largeaud, L.; Deswarte, C.; Jachiet, V.; Mohty, M.; Rivière, S.; Malard, F.; Tenon, M.; de Vassoigne, F.; et al. Clonal haematopoiesis is increased in early onset in systemic sclerosis. Rheumatology (Oxford) 2020, 59, 3499-3504. [CrossRef] [PubMed]

74. Mekinian, A.; Braun, T.; Decaux, O.; Falgarone, G.; Toussirot, E.; Raffray, L.; Omouri, M.; Gombert, B.; De Wazieres, B.; Buchdaul, A.-L.; et al. Inflammatory Arthritis in Patients with Myelodysplastic Syndromes: A Multicenter Retrospective Study and Literature Review of 68 Cases. Medicine 2014, 93, 1-10. [CrossRef]

75. Castro, M.; Conn, D.L.; Su, W.P.; Garton, J.P. Rheumatic manifestations in myelodysplastic syndromes. J. Rheumatol. 1991, 18, 721-727. 
76. Espinosa, G.; Font, J.; Muñoz-Rodríguez, F.J.; Cervera, R.; Ingelmo, M. Myelodysplastic and myeloproliferative syndromes associated with giant cell arteritis and polymyalgia rheumatica: A coincidental coexistence or a causal relationship? Clin. Rheumatol. 2002, 21, 309-313. [CrossRef] [PubMed]

77. Bellan, M.; Boggio, E.; Sola, D.; Gibbin, A.; Gualerzi, A.; Favretto, S.; Guaschino, G.; Bonometti, R.; Pedrazzoli, R.; Pirisi, M.; et al. Association between rheumatic diseases and cancer: Results from a clinical practice cohort study. Intern. Emerg. Med. 2017, 12, 621-627. [CrossRef] [PubMed]

78. Paira, S.; Graf, C.; Roverano, S.; Rossini, J. Remitting seronegative symmetrical synovitis with pitting oedema: A study of 12 cases. Clin. Rheumatol. 2002, 21, 146-149. [CrossRef] [PubMed]

79. Tedeschi, S.K.; Stone, R.M.; Helfgott, S.M. Calcium Pyrophosphate Crystal Inflammatory Arthritis (Pseudogout) with Myelodysplastic Syndrome: A New Paraneoplastic Syndrome? J. Rheumatol. 2017, 44, 1101-1102. [CrossRef] [PubMed]

80. Farah, C.; Bulai Livideanu, C.; Jegu, J.; Paul, C.; Viraben, R.; Lamant, L.; Delavigne, K.; Adoue, D.; Laurent, G.; Beyne Rauzy, O. Prevalence and prognostic value of cutaneous manifestations in patients with myelodysplastic syndrome. J. Eur. Acad Dermatol. Venereol. 2010, 24, 1171-1175. [CrossRef] [PubMed]

81. Yoneta, K.; Fujimoto, N.; Teramura, K.; Takayama, S.; Tanaka, T. Disseminated granulomatous skin lesions associated with myelodysplastic syndrome treated successfully with tranilast: A case report and review of the literature. Eur. J. Dermatol. 2016, 26, 398-400. [CrossRef]

82. Balin, S.J.; Wetter, D.A.; Kurtin, P.J.; Letendre, L.; Pittelkow, M.R. Myelodysplastic syndrome presenting as generalized granulomatous dermatitis. Arch. Dermatol. 2011, 147, 331-335. [CrossRef] [PubMed]

83. Lepelletier, C.; Bouaziz, J.-D.; Rybojad, M.; Bagot, M.; Georgin-Lavialle, S.; Vignon-Pennamen, M.-D. Neutrophilic Dermatoses Associated with Myeloid Malignancies. Am. J. Clin. Dermatol. 2019, 20, 325-333. [CrossRef] [PubMed]

84. Maalouf, D.; Battistella, M.; Bouaziz, J.-D. Neutrophilic dermatosis: Disease mechanism and treatment. Curr. Opin. Hematol. 2015, 22, 23-29. [CrossRef] [PubMed]

85. Cohen, P.R. Sweet's syndrome-a comprehensive review of an acute febrile neutrophilic dermatosis. Orphanet J. Rare Dis. 2007, 2, 34. [CrossRef]

86. Li, Y.; Ai, M.; Yang, W.; Li, X. Vital organ involvement in Sweet's syndrome with myelodysplastic syndrome: A case report and literature review. Int. J. Dermatol. 2015, 54, 1303-1308. [CrossRef]

87. Requena, L.; Kutzner, H.; Palmedo, G.; Pascual, M.; Fernández-Herrera, J.; Fraga, J.; García-Díez, A.; Yus, E.S. Histiocytoid Sweet syndrome: A dermal infiltration of immature neutrophilic granulocytes. Arch. Dermatol. 2005, 141, 834-842. [CrossRef]

88. Chavan, R.N.; Cappel, M.A.; Ketterling, R.P.; Wada, D.A.; Rochet, N.M.; Knudson, R.; Gibson, L.E. Histiocytoid Sweet syndrome may indicate leukemia cutis: A novel application of fluorescence in situ hybridization. J. Am. Acad Dermatol. 2014, 70, 1021-1027. [CrossRef] [PubMed]

89. Alegría-Landa, V.; Rodríguez-Pinilla, S.M.; Santos-Briz, A.; Rodríguez-Peralto, J.L.; Alegre, V.; Cerroni, L.; Kutzner, H.; Requena, L. Clinicopathologic, Immunohistochemical, and Molecular Features of Histiocytoid Sweet Syndrome. JAMA Dermatol. 2017, 153, 651-659. [CrossRef] [PubMed]

90. Ghoufi, L.; Ortonne, N.; Ingen-Housz-Oro, S.; Barhoumi, W.; Begon, E.; Haioun, C.; Pautas, C.; Beckerich, F.; Robin, C.; Wolkenstein, P.; et al. Histiocytoid Sweet Syndrome Is More Frequently Associated With Myelodysplastic Syndromes Than the Classical Neutrophilic Variant: A Comparative Series of 62 Patients. Medicine (Baltimore) 2016, 95, e3033. [CrossRef] [PubMed]

91. Nelson, C.A.; Noe, M.H.; McMahon, C.M.; Gowda, A.; Wu, B.; Ashchyan, H.J.; Perl, A.E.; James, W.D.; Micheletti, R.G.; Rosenbach, M. Sweet syndrome in patients with and without malignancy: A retrospective analysis of 83 patients from a tertiary academic referral center. J. Am. Acad Dermatol. 2018, 78, 303-309.e4. [CrossRef] [PubMed]

92. Van Loon, K.; Gill, R.M.; McMahon, P.; Chigurupati, R.; Siddiqi, I.; Fox, L.; Damon, L.; McCalmont, T.H.; Jordan, R.; Wolf, J. 20q-clonality in a case of oral sweet syndrome and myelodysplasia. Am. J. Clin. Pathol. 2012, 137, 310-315. [CrossRef] [PubMed]

93. Sujobert, P.; Cuccuini, W.; Vignon-Pennamen, D.; Martin-Garcia, N.; Albertini, A.F.; Uzunov, M.; Redjoul, R.; Dombret, H.; Raffoux, E. Evidence of differentiation in myeloid malignancies associated neutrophilic dermatosis: A fluorescent in situ hybridization study of 14 patients. J. Investig. Dermatol. 2013, 133, 1111-1114. [CrossRef] [PubMed]

94. Magro, C.M.; Kiani, B.; Li, J.; Crowson, A.N. Clonality in the setting of Sweet's syndrome and pyoderma gangrenosum is not limited to underlying myeloproliferative disease. J. Cutan. Pathol. 2007, 34, 526-534. [CrossRef] [PubMed]

95. Mo, W.; Wang, X.; Wang, Y.; Li, Y.; Zhang, R. Clonal neutrophil infiltrates in concurrent Sweet's syndrome and acute myeloid leukemia: A case report and literature review. Cancer Genet. 2018, 226-227, 11-16. [CrossRef] [PubMed]

96. Passet, M.; Lepelletier, C.; Vignon-Pennamen, M.-D.; Chasset, F.; Hirsch, P.; Battistella, M.; Duriez, P.; Sicre de Fontbrune, F.; Boissel, N.; Legrand, O.; et al. Next-Generation Sequencing in Myeloid Neoplasm-Associated Sweet's Syndrome Demonstrates Clonal Relation between Malignant Cells and Skin-Infiltrating Neutrophils. J. Investig. Dermatol. 2020, 140, 1873-1876.e5. [CrossRef] [PubMed]

97. Osio, A.; Battistella, M.; Feugeas, J.-P.; Cuccuini, W.; Noguera, M.-E.; Petrella, T.; Raffoux, E.; Janin, A.; Pennamen, V. Myelodysplasia Cutis Versus Leukemia Cutis. J. Investig. Dermatol. 2015, 135, 2321-2324. [CrossRef]

98. Avivi, I.; Rosenbaum, H.; Levy, Y.; Rowe, J. Myelodysplastic syndrome and associated skin lesions: A review of the literature. Leuk. Res. 1999, 23, 323-330. [CrossRef]

99. Ahronowitz, I.; Harp, J.; Shinkai, K. Etiology and management of pyoderma gangrenosum: A comprehensive review. Am. J. Clin. Dermatol. 2012, 13, 191-211. [CrossRef] 
100. Maverakis, E.; Ma, C.; Shinkai, K.; Fiorentino, D.; Callen, J.P.; Wollina, U.; Marzano, A.V.; Wallach, D.; Kim, K.; Schadt, C.; et al. Diagnostic Criteria of Ulcerative Pyoderma Gangrenosum: A Delphi Consensus of International Experts. JAMA Dermatol. 2018, 154, 461-466. [CrossRef] [PubMed]

101. Celada, A.; Farquet, J.J.; Muller, A.F. Refractory sideroblastic anemia secondary to autoimmune hemolytic anemia. Acta Haematol. 1977, 58, 213-216. [CrossRef] [PubMed]

102. Ustwani, O.A.; Ford, L.A.; Sait, S.J.N.; Block, A.M.W.; Barcos, M.; Vigil, C.E.; Griffiths, E.A.; Thompson, J.E.; Wang, E.S.; Ambrus, J.; et al. Myelodysplastic syndromes and autoimmune diseases-Case series and review of literature. Leuk. Res. 2013, 37, 894-899. [CrossRef]

103. Van Rhee, F.; Abela, M. Coombs negative haemolytic anaemia responding to intravenous immunoglobulins in a patient with myelodysplastic syndrome. Clin. Lab. Haematol. 1991, 13, 99-101. [CrossRef] [PubMed]

104. Novaretti, M.C.; Sopelete, C.R.; Velloso, E.R.; Rosa, M.F.; Dorlhiac-Llacer, P.E.; Chamone, D.A. Immunohematological findings in myelodysplastic syndrome. Acta Haematol. 2001, 105, 1-6. [CrossRef] [PubMed]

105. Jachiet, V.; Moulis, G.; Hadjadj, J.; Seguier, J.; Laribi, K.; Schleinitz, N.; Vey, N.; Sacre, K.; Godeau, B.; Beyne-Rauzy, O.; et al. Clinical spectrum, outcome and management of immune thrombocytopenia associated with myelodysplastic syndromes and chronic myelomonocytic leukemia. Haematologica 2021, 106, 1414. [CrossRef] [PubMed]

106. Arber, D.A.; Orazi, A.; Hasserjian, R.; Thiele, J.; Borowitz, M.J.; Le Beau, M.M.; Bloomfield, C.D.; Cazzola, M.; Vardiman, J.W. The 2016 revision to the World Health Organization classification of myeloid neoplasms and acute leukemia. Blood 2016, 127, 2391-2405. [CrossRef]

107. Malcovati, L.; Gallì, A.; Travaglino, E.; Ambaglio, I.; Rizzo, E.; Molteni, E.; Elena, C.; Ferretti, V.V.; Catricalà, S.; Bono, E.; et al. Clinical significance of somatic mutation in unexplained blood cytopenia. Blood 2017, 129, 3371-3378. [CrossRef]

108. Barcellini, W.; Fattizzo, B.; Zaninoni, A.; Valli, V.; Ferri, V.; Gianelli, U.; Cortelezzi, A. Clinical evolution of autoimmune cytopenias to idiopathic cytopenias/dysplasias of uncertain significance (ICUS/IDUS) and bone marrow failure syndromes. Am. J. Hematol. 2017, 92, E26-E29. [CrossRef]

109. Tabata, R.; Tabata, C.; Omori, K.; Nagai, T. Disappearing myelodysplastic syndrome-associated hemolytic anemia in leukemic transformation. Int Arch. Allergy Immunol. 2010, 152, 407-412. [CrossRef]

110. Beck, D.B.; Ferrada, M.A.; Sikora, K.A.; Ombrello, A.K.; Collins, J.C.; Pei, W.; Balanda, N.; Ross, D.L.; Ospina Cardona, D.; Wu, Z.; et al. Somatic Mutations in UBA1 and Severe Adult-Onset Autoinflammatory Disease. N. Engl. J. Med. 2020, 383, 2628-2638. [CrossRef]

111. Obiorah, I.E.; Beck, D.B.; Wang, W.; Ombrello, A.; Ferrada, M.A.; Wu, Z.; Sikora, K.A.; Trick, M.A.; Dulau-Florea, A.; Patel, B.A.; et al. Myelodysplasia and Bone Marrow Manifestations of Somatic UBA1 Mutated Autoinflammatory Disease. Blood 2020, 136, 20-21. [CrossRef]

112. Oganesyan, A.; Jachiet, V.; Chasset, F.; Hirsch, P.; Hage-Sleiman, M.; Fabiani, B.; Duriez, P.; Georgin-Lavialle, S.; Delhommeau, F.; Hakobyan, Y.; et al. VEXAS syndrome: Still expanding the clinical phenotype. Rheumatology (Oxford) 2021. [CrossRef] [PubMed]

113. Ishii, H.; Tazawa, R.; Kaneko, C.; Saraya, T.; Inoue, Y.; Hamano, E.; Kogure, Y.; Tomii, K.; Terada, M.; Takada, T.; et al. Clinical features of secondary pulmonary alveolar proteinosis: Pre-mortem cases in Japan. Eur. Respir. J. 2011, 37, 465-468. [CrossRef] [PubMed]

114. Wang, Z.; Zhou, Y.; Liu, Y. Concurrent inflammatory bowel disease and myelodysplastic syndrome: Report of nine new cases and a review of the literature. Dig. Dis. Sci. 2008, 53, 1929-1932. [CrossRef] [PubMed]

115. Fraison, J.-B.; Grignano, E.; Braun, T.; Adès, L.; Chollet-Martin, S.; Roland-Nicaise, P.; Fenaux, P.; Fain, O.; Mekinian, A. Autoantibodies in myelodysplastic syndromes and chronic myelomonocytic leukemia. Leuk. Lymphoma 2019, 60, $2594-2596$. [CrossRef] [PubMed]

116. Okamoto, T.; Okada, M.; Mori, A.; Saheki, K.; Takatsuka, H.; Wada, H.; Tamura, A.; Fujimori, Y.; Takemoto, Y.; Kanamaru, A.; et al. Correlation between immunological abnormalities and prognosis in myelodysplastic syndrome patients. Int. J. Hematol. 1997, 66, 345-351. [CrossRef]

117. Zhao, S.; Mao, H.; Wang, H.; Yu, J. The relationship between myelodysplastic syndromes and autoimmune disorders. Zhonghua Xue Ye Xue Za Zhi 2002, 23, 311-313.

118. Lee, S.J.; Park, J.K.; Lee, E.Y.; Joo, S.H.; Jung, K.C.; Lee, E.B.; Song, Y.W.; Yoon, S.-S. Certain Autoimmune Manifestations Are Associated With Distinctive Karyotypes and Outcomes in Patients With Myelodysplastic Syndrome: A Retrospective Cohort Study. Medicine 2016, 95, e3091. [CrossRef]

119. Montoro, J.; Gallur, L.; Merchán, B.; Molero, A.; Roldán, E.; Martínez-Valle, F.; Villacampa, G.; Navarrete, M.; Ortega, M.; Castellví, J.; et al. Autoimmune disorders are common in myelodysplastic syndrome patients and confer an adverse impact on outcomes. Ann. Hematol. 2018, 97, 1349-1356. [CrossRef]

120. Ertz-Archambault, N.; Kosiorek, H.; Taylor, G.E.; Kelemen, K.; Dueck, A.; Castro, J.; Marino, R.; Gauthier, S.; Finn, L.; Sproat, L.Z.; et al. Association of Therapy for Autoimmune Disease With Myelodysplastic Syndromes and Acute Myeloid Leukemia. JAMA Oncol. 2017, 3, 936-943. [CrossRef]

121. Mekinian, A.; Dervin, G.; Lapidus, N.; Kahn, J.-E.; Terriou, L.; Liozon, E.; Grignano, E.; Piette, J.-C.; Rauzy, O.B.; Grobost, V.; et al. Biologics in myelodysplastic syndrome-related systemic inflammatory and autoimmune diseases: French multicenter retrospective study of 29 patients. Autoimmun. Rev. 2017, 16, 903-910. [CrossRef] [PubMed] 
122. Thieu, K.P.; Rosenbach, M.; Xu, X.; Kist, J.M. Neutrophilic dermatosis complicating lenalidomide therapy. J. Am. Acad Dermatol. 2009, 61, 709-710. [CrossRef]

123. Tageja, N.; Giorgadze, T.; Zonder, J. Dermatological complications following initiation of lenalidomide in a patient with chronic lymphocytic leukaemia. Intern. Med. J. 2011, 41, 286-288. [CrossRef] [PubMed]

124. Hoverson, A.R.; Davis, M.D.P.; Weenig, R.H.; Wolanskyj, A.P. Neutrophilic dermatosis (Sweet syndrome) of the hands associated with lenalidomide. Arch. Dermatol. 2006, 142, 1070-1071. [CrossRef]

125. Saadoun, D.; Rosenzwajg, M.; Joly, F.; Six, A.; Carrat, F.; Thibault, V.; Sene, D.; Cacoub, P.; Klatzmann, D. Regulatory T-cell responses to low-dose interleukin-2 in HCV-induced vasculitis. N. Engl. J. Med. 2011, 365, 2067-2077. [CrossRef] [PubMed]

126. Rosenzwajg, M.; Lorenzon, R.; Cacoub, P.; Pham, H.P.; Pitoiset, F.; El Soufi, K.; RIbet, C.; Bernard, C.; Aractingi, S.; Banneville, B.; et al. Immunological and clinical effects of low-dose interleukin-2 across 11 autoimmune diseases in a single, open clinical trial. Ann. Rheum. Dis. 2019, 78, 209-217. [CrossRef]

127. Corfmat, M.; Willekens, C.; Vinit, J.; Bussone, G.; Fenaux, P.; Fain, O.; Klatzmann, D.; Mekinian, A.; Comont, T. Low dose IL-2 in patients with steroid-dependent dysimmune manifestations associated with myelodysplastic syndromes: A three-case report. Rheumatology (Oxford) 2020. [CrossRef]

128. Verstovsek, S.; Mesa, R.A.; Gotlib, J.; Levy, R.S.; Gupta, V.; DiPersio, J.F.; Catalano, J.V.; Deininger, M.; Miller, C.; Silver, R.T.; et al. A double-blind, placebo-controlled trial of ruxolitinib for myelofibrosis. N. Engl. J. Med. 2012, 366, 799-807. [CrossRef]

129. Zeiser, R.; von Bubnoff, N.; Butler, J.; Mohty, M.; Niederwieser, D.; Or, R.; Szer, J.; Wagner, E.M.; Zuckerman, T.; Mahuzier, B.; et al. Ruxolitinib for Glucocorticoid-Refractory Acute Graft-versus-Host Disease. N. Engl. J. Med. 2020, 382, 1800-1810. [CrossRef]

130. Schwartz, D.M.; Kanno, Y.; Villarino, A.; Ward, M.; Gadina, M.; O'Shea, J.J. JAK inhibition as a therapeutic strategy for immune and inflammatory diseases. Nat. Rev. Drug Discov. 2017, 17, 78. [CrossRef]

131. Bourbon, E.; Heiblig, M.; Gerfaud-Valentin, M.; Barba, T.; Durel, C.A.; Lega, J.-C.; Barraco, F.; Seve, P.; Jamilloux, Y.; Sujobert, P. Therapeutic options in Vexas syndrome: Insights from a retrospective series. Blood 2021. [CrossRef] [PubMed]

132. Fenaux, P.; Haase, D.; Santini, V.; Sanz, G.F.; Platzbecker, U.; Mey, U. Myelodysplastic syndromes: ESMO Clinical Practice Guidelines for diagnosis, treatment and follow-up. Ann. Oncol. 2021, 32, 142-156. [CrossRef] [PubMed]

133. Raj, K.; Ho, A.; Creamer, J.D.; du Vivier, A.W.P.; Salisbury, J.R.; Mufti, G.J. Complete response of deep neutrophilic dermatosis associated with myelodysplastic syndrome to 5-azacytidine. Br. J. Dermatol. 2007, 156, 1039-1041. [CrossRef]

134. Al Ustwani, O.; Francis, J.; Wallace, P.K.; Ambrus, J.; Wetzler, M. Treating myelodysplastic syndrome improves an accompanying autoimmune disease along with a reduction in regulatory T-cells. Leuk. Res. 2011, 35, e35-e36. [CrossRef]

135. Frietsch, J.J.; Dornaus, S.; Neumann, T.; Scholl, S.; Schmidt, V.; Kunert, C.; Sayer, H.G.; Hochhaus, A.; La Rosée, P. Paraneoplastic inflammation in myelodysplastic syndrome or bone marrow failure: Case series with focus on 5-azacytidine and literature review. Eur. J. Haematol. 2014, 93, 247-259. [CrossRef]

136. Pilorge, S.; Doleris, L.M.; Dreyfus, F.; Park, S. The autoimmune manifestations associated with myelodysplastic syndrome respond to 5-azacytidine: A report on three cases. Br. J. Haematol. 2011, 153, 664-665. [CrossRef] [PubMed]

137. Kudo, D.; Shimizu, M.; Kuroda, A.; Suyama, T.; Shinagawa, A.; Ito, S. Myelodysplastic syndrome with neutrophilic dermatosis successfully treated with azacitidine. Rinsho Ketsueki 2017, 58, 607-612.

138. Kono, M.; Komeda, Y.; Sakurai, T.; Okamoto, A.; Minaga, K.; Kamata, K.; Hagiwara, S.; Inoue, H.; Enoki, E.; Matsumura, I.; et al. Induction of Complete Remission by Azacitidine in a Patient with Myelodysplastic Syndrome-Associated Inflammatory Bowel Disease. J. Crohns Colitis 2018, 12, 499-502. [CrossRef]

139. Erden, A.; Bilgin, E.; Kılı̧̧, L.; Sarı, A.; Armağan, B.; Büyükaşık, Y.; Kalyoncu, U. Remission of relapsing polychondritis after successful treatment of myelodysplastic syndrome with azacitidine: A case and review of the literature. Drug Metab. Pers. Ther. 2018, 33, 105-108. [CrossRef]

140. Costantini, B.; Kordasti, S.Y.; Kulasekararaj, A.G.; Jiang, J.; Seidl, T.; Abellan, P.P.; Mohamedali, A.; Thomas, N.S.B.; Farzaneh, F.; Mufti, G.J. The effects of 5-azacytidine on the function and number of regulatory T cells and T-effectors in myelodysplastic syndrome. Haematologica 2013, 98, 1196-1205. [CrossRef]

141. Bontkes, H.J.; Ruben, J.M.; Alhan, C.; Westers, T.M.; Ossenkoppele, G.J.; van de Loosdrecht, A.A. Azacitidine differentially affects CD4pos T-cell polarization in vitro and in vivo in high risk myelodysplastic syndromes. Leuk. Res. 2012, 36, 921-930. [CrossRef]

142. Goodyear, O.C.; Dennis, M.; Jilani, N.Y.; Loke, J.; Siddique, S.; Ryan, G.; Nunnick, J.; Khanum, R.; Raghavan, M.; Cook, M.; et al. Azacitidine augments expansion of regulatory $\mathrm{T}$ cells after allogeneic stem cell transplantation in patients with acute myeloid leukemia (AML). Blood 2012, 119, 3361-3369. [CrossRef]

143. Sohlberg, E.; Pfefferle, A.; Andersson, S.; Baumann, B.C.; Hellström-Lindberg, E.; Malmberg, K.-J. Imprint of 5-azacytidine on the natural killer cell repertoire during systemic treatment for high-risk myelodysplastic syndrome. Oncotarget 2015, 6, 34178-34190. [CrossRef]

144. Gang, A.O.; Frøsig, T.M.; Brimnes, M.K.; Lyngaa, R.; Treppendahl, M.B.; Grønbæk, K.; Dufva, I.H.; Straten, P.T.; Hadrup, S.R. 5-Azacytidine treatment sensitizes tumor cells to T-cell mediated cytotoxicity and modulates NK cells in patients with myeloid malignancies. Blood Cancer J. 2014, 4, e197. [CrossRef]

145. Kopp, L.M.; Ray, A.; Denman, C.J.; Senyukov, V.S.; Somanchi, S.S.; Zhu, S.; Lee, D.A. Decitabine has a biphasic effect on natural killer cell viability, phenotype, and function under proliferative conditions. Mol. Immunol. 2013, 54, 296-301. [CrossRef] [PubMed]

146. Frikeche, J.; Clavert, A.; Delaunay, J.; Brissot, E.; Grégoire, M.; Gaugler, B.; Mohty, M. Impact of the hypomethylating agent 5-azacytidine on dendritic cells function. Exp. Hematol. 2011, 39, 1056-1063. [CrossRef] 
147. Zhou, J.; Yao, Y.; Shen, Q.; Li, G.; Hu, L.; Zhang, X. Demethylating agent decitabine disrupts tumor-induced immune tolerance by depleting myeloid-derived suppressor cells. J. Cancer Res. Clin. Oncol. 2017, 143, 1371-1380. [CrossRef] [PubMed]

148. Poplutz, M.K.; Wessels, I.; Rink, L.; Uciechowski, P. Regulation of the Interleukin-6 gene expression during monocytic differentiation of HL-60 cells by chromatin remodeling and methylation. Immunobiology 2014, 219, 619-626. [CrossRef]

149. Fraison, J.-B.; Mekinian, A.; Grignano, E.; Kahn, J.-E.; Arlet, J.-B.; Decaux, O.; Denis, G.; Buchdahl, A.-L.; Omouri, M.; Maigne, G.; et al. Efficacy of Azacitidine in autoimmune and inflammatory disorders associated with myelodysplastic syndromes and chronic myelomonocytic leukemia. Leuk. Res. 2016, 43, 13-17. [CrossRef]

150. Yamato, K. Successful cord blood stem cell transplantation for myelodysplastic syndrome with Behçet disease. Int. J. Hematol. 2003, 77, 82-85. [CrossRef]

151. Tomonari, A.; Tojo, A.; Takahashi, T.; Iseki, T.; Ooi, J.; Takahashi, S.; Nagamura, F.; Uchimaru, K.; Asano, S. Resolution of Behçet's disease after HLA-mismatched unrelated cord blood transplantation for myelodysplastic syndrome. Ann. Hematol. 2004, 83, 464-466. [CrossRef] [PubMed]

152. Nonami, A.; Takenaka, K.; Sumida, C.; Aizawa, K.; Kamezaki, K.; Miyamoto, T.; Harada, N.; Nagafuji, K.; Teshima, T.; Harada, M. Successful treatment of myelodysplastic syndrome (MDS)-related intestinal Behçet's disease by up-front cord blood transplantation. Intern. Med. 2007, 46, 1753-1756. [CrossRef] [PubMed]

153. Tomomatsu, J.; Hamano, Y.; Ando, J.; Komatsu, N.; Sugimoto, K. Non-myeloablative allogenic BMT for myelodysplastic syndrome successfully controlled accompanying relapsing polychondritis. Bone Marrow Transplant. 2012, 47, 742-743. [CrossRef] [PubMed]

154. Kook, M.-H.; Yhim, H.-Y.; Lee, N.-R.; Song, E.-K.; Kim, H.S.; Yim, C.-Y.; Kwak, J.-Y. Successful treatment of myelodysplastic syndrome and Behcet colitis after allogeneic hematopoietic stem cell transplantation. Korean J. Intern. Med. 2014, 29, 123-125. [CrossRef]

155. Soysal, T.; Salihoğlu, A.; Esatoğlu, S.N.; Gültürk, E.; Eşkazan, A.E.; Hatemi, G.; Hatemi, I.; Öngören Aydın, Ş.; Erzin, Y.Z.; Başlar, Z.; et al. Bone marrow transplantation for Behçet's disease: A case report and systematic review of the literature. Rheumatology (Oxford) 2014, 53, 1136-1141. [CrossRef] [PubMed]

156. Lee, S.-S.; Ahn, J.-S.; Yun, S.J.; Park, D.-J. Successful treatment of a patient with myelodysplastic syndrome accompanied by pyoderma gangrenosum and Behçet's disease using allogeneic stem cell transplantation. Blood Res. 2017, 52, 319-321. [CrossRef]

157. Daikeler, T.; Hügle, T.; Farge, D.; Andolina, M.; Gualandi, F.; Baldomero, H.; Bocelli-Tyndall, C.; Brune, M.; Dalle, J.H.; Urban, C.; et al. Allogeneic hematopoietic SCT for patients with autoimmune diseases. Bone Marrow Transplant. 2009, 44, 27-33. [CrossRef]

158. Snowden, J.A.; Badoglio, M.; Labopin, M.; Giebel, S.; McGrath, E.; Marjanovic, Z.; Burman, J.; Moore, J.; Rovira, M.; Wulffraat, N.M.; et al. Evolution, trends, outcomes, and economics of hematopoietic stem cell transplantation in severe autoimmune diseases. Blood Adv. 2017, 1, 2742-2755. [CrossRef] 